\title{
Performance of Solid Waste Services in Sampit
} City

\author{
Sharifa Emira ${ }^{1}$, Danang Biyatmoko², Mufidah Asyari³, EkoRini Indrayatie ${ }^{4}$
}

${ }^{1}$ Department of Natural Resources and Environmental Management Postgraduate Program University of Lambung Mangkurat, South Kalimantan, Indonesia

${ }^{2}$ Faculty of Agriculture University of Lambung Mangkurat, South Kalimantan, Indonesia

${ }^{3,4}$ Faculty of Forestry University of Lambung Mangkurat, South Kalimantan, Indonesia

\begin{abstract}
This study aims to determine the performance of waste management services in the city of Sampit with the study locations in MentawaBaruHilir Village and Ketapang Village, MentawaBaru Village, District Ketapang, Baamang Hulu Village and Baamang Tengah Village, Baamang District. The factors studied are the completeness of waste management facilities (X1); household garbage collection (X2); frequency of garbage transportation (X3); community participation (X4); and socialization activities on household waste management (X5). This research was conducted by distributing questionnaires to 100 people in the study area. After that, multiple linear regression analysis was carried out with the SPSS program. From the factors studied, the results are obtained factor of frequency factor of garbage transport the value of regression coefficient 1.348 and probability value 0.007; socialization of household waste management with regression coefficient value of 1.348 and 0.033 probability value; the garbage collection factor of the household regression coefficient value is 1.182 and the probability value is 0.001 ; factor of completeness of waste management facilities the value of regression coefficient of 0.985 and probability value of 0.021 ; and community participation factors the value of regression coefficient 0.955 and probability value 0.019 .
\end{abstract}

Keywords-Solid waste service performance, Waste management facilities, community participation.

\section{INTRODUCTION}

Kotawaringin Timur Regency with $16.496 \mathrm{~km}^{2}$ land area with the capital of regency is placed in Sampit City, The Sampit City itself consists of 3 sub-districts which are Baaman sub-districts, Mentawa Baru Ketapang Sub-Districts, and Seranau Sub-Districts with 155.853 total population (BPS, 2018). While to cover the waste management services, until recent day, Department of Environment in Kotawaringin Timur regency can only serve 2 Sub-Districts which are Baamang Sub-Districts and Mentawa Baru Ketapang Sub-Districts with 145.853 total population (BPS, 2018).

According to EHRA's study reports in 2013, the questionnaire results showed that $59,1 \%$ of household waste management is still burned, $18,4 \%$ is thrown into the river, and $1,9 \%$ is thrown into the hole inside the soil and the hole with a pile of garbage is not covered. Meanwhile for the sorting waste from household activities, $89,7 \%$ of the waste is not sorted but directly thrown into a waste bin while the rest $10,3 \%$ of it is sorted before it is thrown.

As mentioned above, it is needed to give environmental information and to do a study about waste management services in Sampit City which can be used as reference in planning and budgeting the waste management services. This environmental information system is aimed to help people understand about garbage generation and waste management services in Sampit city.

\section{Problem Outline}

Problem outline of this study is to determine the performance of waste management services with studied factors such as waste management facilities (X1); waste collection from household (X2); waste transportation frequency (X3); Community's participation (X4); and socialization of household waste management (X5).

\section{Objectives}

The objectives of this study are:

1. Analyzing the correlation degree between the variable of waste management facilities, the variable of household waste collection; the variable of community's participation; and the variable of socialization of household waste management.

2. Analyzing the most dominant correlation degree between the variable of waste management facilities, the variable of household waste collection; the 
variable of community's participation; and the variable of socialization of household waste management.

\section{METHOD STUDY}

Respondent calculation method

Generally, the number of sample size that needed to be taken can be measured by using slovin formulation

Information :

$$
n=\frac{N}{N x(e)^{2}+1}
$$

$\mathrm{n}=$ number of samples

$\mathrm{N}=$ total population

e $=$ critical number / error tolerance $(10 \%)$

Based on Slovin formulation up above, the calculation of total resposdentsis :

$$
\begin{aligned}
& n=\frac{145.853}{145.853 \times(0,1)^{2}+1} \\
& =99,93=100 \text { respondents }
\end{aligned}
$$

Based on the calculation as mentioned above, 100 respondents are obtained, thus, for each regency the calculation of total respondents are:

a. Total respondents in MentawaBaruKetapang SubDistricts

Total respondents

$$
\begin{aligned}
& =100 \text { respondents } \times\left(\frac{86.839}{145.853} \times 100 \%\right) \\
& =59,5=60 \text { respondents }
\end{aligned}
$$

b. Total respondents in Baamang Sub-Districts

Total respondents

$=100$ respondents $\times\left(\frac{59.014}{145.853} \times 100 \%\right)$

$=40,4=40$ respondents

\section{Data Analysis Method}

The data collection is shown in table and charts, based on the score calculation obtained from each variable score as mentioned down below:
a. 4 score $=$ all criteria are met;
b. 3 score $=3$ (three) criteria are met;
c. 2 score $=2$ (two) criteria are met; and
d. 1 score $=1$ (one) criteria is met.

Performance analysis of waste management services is using multiple linear regression analysis with SPSS program to determine the factors that affect waste management services. Specificity formula of multiple linear regression are :

$\mathrm{Y}=\alpha+\beta 1 . \mathrm{X} 1+\beta 2 . \mathrm{X} 2+\beta 3 . \mathrm{X} 3+\beta 4 . \mathrm{X} 4+\beta 5 . \mathrm{X} 5+\varepsilon \mathrm{i}$ Information :

$\mathrm{Y}=$ Waste management service performance $\alpha=$ Intercept

$\beta=$ Regression coefficient

ci $=$ Error Factor

$\mathrm{X}_{1}=$ Waste management facilities

$\mathrm{X}_{2}=$ Hous ehold waste collection

$\mathrm{X}_{3}=$ Waste transport frequency

$\mathrm{X}_{4}=$ Community participations

$\mathrm{X}_{5}=$ Socialization of household waste management

\section{RESULTS AND DISCUSSIONS}

Based on the study results of waste management performance that has been carried out by Raharjo (2016) with a case study of Pangkalan Bun City, Kotawaringin Barat Regency, it has been said that the performance of waste management services is influenced by the most dominant factors which are community's participation. The study was conducted with data collection techniques for analyzing the performance of waste management services by using respondents through questionnaires. The results of this study analyze the factors that affect the performance of waste management, which are Organization and management; operational techniques; financing; regulations; and community participation.

Based on the studies related to the factors that influence waste management which has been done in a case study of the Tangerang Regency by Widyarsana and Zafira (2015), the following results are:

a. Waste disposal needs to be separated into 3 (three) types of sorting and placed in community housing

b. Laws and regulations, this is seen as very influential in the waste management system because there is no strict action for people who do not obey the regulations, it is difficult to implement the rules that have been made to the whole society and also lack of socialization.

c. Institutional structure of the organization that has not been supported by the number and the quality of human resources and the lack of cooperation between the Regional Government and NGOs in the household waste management.

d. Financing needs to be optimized both from private investment and regional budgets for the costs of operational activities and maintenance of waste management facilities and infrastructure.

e. The active participation of the community in the household waste management is very necessary, such as providing trash bins for each house, reducing the source (household) and anticipating public awareness to pay contributions or waste retribution to support waste management operations. 
Statistical tests on the regression coefficient of waste management service performance in Sampit City use multiple linear regression analysis and are processed through the SPSS program. This analysis is used to predict the value of non-independent variables $(\mathrm{Y})$ if the independent variables are more than 2 (two) variables. This study is using 5 (five) independent variables, which are the completeness of waste management facilities (X1), waste collection from household (X2); waste transportation frequency (X3); Community's participation (X4); and socialization of household waste management (X5), the non-independent variable is the performance of waste management services (Y).

\section{Hypothesis Testing}

Hypothesis testing in this study is conducted by testing the significance of regression coefficient. To determine the collective effect of independent variables using the $\mathrm{F}$ test and to determine the effect of each independent variable partially by using the T test.

\section{Simultaneous Influence Test (F Test)}

Simultaneous test (F test) aims to determine whether there is a simultaneous effect (together) given by the independent variable $(\mathrm{X})$ on the dependent variable (Y). The results of the simultaneous test (Test F) are shown in Table 1.

Table 1. F Test Result Analysis

\begin{tabular}{|l|l|l|l|l|l|}
\hline Model & $\begin{array}{c}\text { Number } \\
\text { of } \\
\text { Squares }\end{array}$ & $\begin{array}{c}\text { df } \\
\text { Aver } \\
\text { age } \\
\text { Squa } \\
\text { res }\end{array}$ & F & Sig \\
\hline Regresi & 22,476 & 4 & 4,495 & 42,383 & $\begin{array}{l}0,001 \\
\text { a }\end{array}$ \\
\hline $\begin{array}{l}\text { Residu } \\
\text { al }\end{array}$ & 0,424 & 5 & 0,106 & & \\
\hline Total & $\mathbf{2 2 , 9 0 0}$ & $\mathbf{9}$ & & & \\
\hline
\end{tabular}

Source : Result Analysis, 2019

Based on Table 1, it can be explained that the fifth level of significant independent variables is 0.001 . Therefore the probability is far less than $0.05(0.001<0.05)$. F-table value of 5.05 is obtained at a significance level of 0.05 then F-count (42.383)> F-table (5.05). Thus $\mathrm{H}_{0}$ is rejected and $\mathrm{H}_{1}$ is accepted, so that it can be concluded that the independent variables in this study can collectively have a great and significant impact on the non-dependent variable, which is the performance of waste management services.

\section{Partial Influence Test (T-Test)}

The $t$ test aims to determine whether or not there is a partial (own) influence given by variable (X) on nonindependent variables (Y). The results of the test of the five independent variables can be seen in Table 2 .

Table 2. T-Test Results

\begin{tabular}{|l|l|l|l|l|}
\hline $\begin{array}{l}\text { Independent } \\
\text { Variables }\end{array}$ & Coeff. & $\begin{array}{l}\text { T- } \\
\text { table }\end{array}$ & T-test & Sig \\
\hline $\begin{array}{l}\text { The } \\
\text { completenes s of } \\
\text { waste } \\
\text { management } \\
\text { facilities }\end{array}$ & 0,985 & 2,776 & 3,673 & 0,021 \\
\hline $\begin{array}{l}\text { Waste collection } \\
\text { from household }\end{array}$ & 1,182 & 2,776 & 9,827 & 0,001 \\
\hline $\begin{array}{l}\text { Waste } \\
\text { transportation } \\
\text { frequency }\end{array}$ & 1,348 & 2,776 & 5,029 & 0,007 \\
\hline $\begin{array}{l}\text { Community } \\
\text { participation }\end{array}$ & 0,955 & 2,776 & 3,777 & 0,019 \\
\hline $\begin{array}{l}\text { Socialization of } \\
\text { household waste } \\
\text { management }\end{array}$ & 1,348 & 2,776 & 3,196 & 0,033 \\
\hline
\end{tabular}

Source : Result Analysis, 2019

Based on Table 2 above it can be explained that the partial effect of each independent variable (X) on the performance of Waste Management Service (Y), as follows:

a. The effect of variable completeness of waste management facilities.

Table 2 shows the level of significant for the variables completeness of waste management facilities is 0.021 $<0.05$ with a t-count value of $3.673>$ t-table 2.776 , so that the variables completeness of waste management facilities have a great and significant impact for the performance of waste management services. The results showed that the completeness of the waste management facilities was the fourth factor influencing the performance of waste management services as shown in the coefficient of 0.985 .

b. The effect of variable waste collection from household Table 2 shows the level of significant for the variable completeness of waste management facilities is 0.001 $<0.05$ with a value of $9,827>$ t-table 2,776 , the variable of waste collection from households has a great and significant impact for the non-independent variable (performance ofwaste management service). The results showed that the waste collection factor from the 
household was the third factor affecting the performance of solid waste services as shown in the coefficient of 1,182 .

From the results of interviews with respondents, the community has already sorted the waste from households. So far, the community has sorted out economically valuable waste such as plastic bottles, glass bottles and sorts that can be sold back to garbage collectors. In an interview in Baamang Hulu Urban Village, Baamang Sub-District there were 7 (seven) households that were members of an independent Environmentally Aware Waste Bank. Those who are members of the Waste Bank actively sort out economic-value waste to be submitted to the Environmentally Aware Waste Bank.

Based on research conducted by Selomo, et al (2016) with the case study of PelitaHarapan Waste Bank in Makassar City, that the knowledge level of the community influences participation in the membership of the Waste Bank. The results of the study determined the factors of community participation in saving at PelitaHarapan Waste Bank, which are the number of family members, income factors and knowledge level factors. Where respondents with sufficient knowledge about Waste Bank participated in the Waste Bank as many as 89 respondents or $76.1 \%$ and 28 respondents or 23.9\% did not participate in the Waste Bank.

Related to the Waste Bank research conducted by Nugraha, et al (2018) with a case study of Rajawati Garbage Bank in South Jakarta, that from the results of the recommendations of Waste Bank customers, it was agreed that Waste Bank management would be carried out continuously as much as $96.77 \%$. Respondents stated that the accumulated waste can have a negative impact on the environment, waste must be sorted before being disposed of in the trash bin. By sorting the waste from the source, it will ease the waste management. Household waste management is influenced by internal factors, which are age, sex, education, employment, income, knowledge, and practice. Whereas external factors are the role of government and infrastructure.

Based on the results of study conducted by the author and in line with studies conducted on Waste Banks in Makassar City and South Jakarta, that community participation in sorting waste activities from their sources (households) and the participation of local governments which also complemented by supporting Waste Bank equipment also affect the waste management process. By sorting economically valuable waste sources that can be reused, it can reduce the amount of waste entering the landfill. c. Effect of variable waste transportation frequency

Table 2 shows the level of significant for the variable completeness of waste management facilities amounting to $0.007<0.05$ with a calculated value of 5.029> t-table 2.77645 , the variable waste transportation frequency has a great and significant impact for the non-independent variable (performance of waste management service). The results showed that the waste transportation frequency was the most dominant factor that influence the performance of waste management service as shown in the coefficient value of 1.348 .

d. Effect of variable community participation

Table 2 shows the level of significant for the variable completeness of waste management facilities amounting to $0.019<0.05$ with a t-count value of $3.777>$ t-table 2.77645 , the role of community participation has a great and significant impact for the non-independent variable (performance of waste management service). The results showed that the factors of community participation were the fifth influencing factor in the performance of waste management service as shown in the coefficient of 0.955 .

e. Effect of Variable socialization household waste management

Table 2 shows the level of significant for the variable completeness of waste management facilities amounting to $0.033<0.05$ with a t-count value of 3.196> t-table 2.77645 , then the variable socialization of household waste management has a great and significant impact for the non-independent variable (performance of waste management service). The results of the study showed that the factors in the socialization of household waste management were the second influencing factor in the performance of waste management service as shown in the coefficient value of 1,348 .

\section{Coefficient of Determination ( $\mathrm{R}$ square)}

To determine how great the independent variables (X) affect the dependent variable (Y), which is Waste Management Service Performance, as shown in the coefficient of determination (R2). The coefficient of determination can be seen in Table 3 .

Table 3 squareResult Analysis

\begin{tabular}{|c|c|c|c|c|}
\hline Model & $\mathbf{R}$ & $\mathbf{R}^{\mathbf{2}}$ & Adj.R & $\begin{array}{c}\text { Std.Estim } \\
\text { asi Error }\end{array}$ \\
\hline 1 & $\begin{array}{c}0,991 \\
\mathrm{a}\end{array}$ & 0,981 & 0,958 & 0,326 \\
\hline
\end{tabular}

Source : Result analysis, 2019 
To determine the accuracy of the independent variable in explaining the non-independent variable can be known from the value of the coefficient multiple determination (R2). The value of $\mathrm{R}$ square (coefficient multiple determinations) is used to see how close the relation between all the independent variables towards the nonindependent variable. The value of $\mathrm{R}$ square in this study was 0.981 . This shows that $98.1 \%$ of the variables are from waste management facilities (X1), waste collection from households (X2), waste transportation frequency (X3), community participation (X4), and socialization of household waste management (X5) while the remaining $1.9 \%$ is explained by other factors outside the model.

\section{CONCLUSION}

Based on the explained study results, the conclusions can be taken as follows:

1. The variables that affect the performance of waste management services start from the first to the fifth dominant influence, respectively the frequency factor of waste transportation with the regression coefficient value of 1.348 and the probability value of 0.007 ; Factor of socializing of household waste management value of regression coefficient 1.348 and probability value 0.033 ; the waste collection factor of the household regression coefficient value is 1.182 and the probability value is 0.001 ; factor of completeness of waste management facilities the value of regression coefficient of 0.985 and probability value of 0.021 ; and community participation factors the value of regression coefficient 0.955 and probability value 0.019 .

2. Variables that have the most dominant level in relation to the performance of waste management services in Sampit City are the variable frequency of waste transportation.

\section{RECOMMENDATIONS}

Based on the explained study results, recommendations can be taken as follows:

1. This study results can become a recommendation for technical institution in order to improve the service performance of waste management.

2. This study results can be continued to further study to optimize the retribution collection in waste management service.

\section{REFERENCES}

[1] Hidayat, A. (2018). The definition of Random Sampling, Types and Sample. https://www.statistikian.com/2018/02/pengertian-simplerandom-sampling.html.

[2] Nugraha, A., S.H. Sutjahjo., and A.A. Amin. Community's Perception and Participation Towards Household Waste Management Through The Waste Bank in South Jakarta. 2018. Journal of Natural Resources and Environmental Management, 8 (1) : 7 - 14.

[3] Raharjo, A.T. (2016). Waste Management Performance in Pangkalan Bun City, Kotawaringin Barat Regency. Juristek, 5, $141-148$.

[4] Widyarsana, I.M.W., and A.D.Zafira. (2015). Study of Waste Management Development System in Tangerang Regency. Journal of Environmental Engineering,21, 87 97.

[5] Selomo, M., A.B. Birawida., A. Mallongi., and Muamar. 2016. Waste Bank as One of Waste Management Solutions in Makassar City. Journal of Indonesian Public Health Media, 12 (4) : 232 - 240. 